\title{
Treatment of copper deficiency in Texel-crossbred sheep by the feeding of a concentrate formulated for dairy cows
}

\author{
Koperdeficiëntie bij schapen (kruising texelaar) behandeld met het \\ voeren van koeienbrok
}

\author{
${ }^{1}$ L. Noorman, ${ }^{2}$ A.F.G. Antonis, ${ }^{1}$ R. Jorritsma, ${ }^{1}$ J.T. Schonewille \\ ${ }^{1}$ Department of Population Health Sciences, Faculty of Veterinary Medicine, Utrecht University, \\ Yalelaan 7, NL-3584-CL, Utrecht, the Netherlands \\ ${ }^{2}$ Wageningen Bioveterinary Research, P.O. Box 65, NL-8200-AB, Lelystad, the Netherlands
}

1.noorman@uu.nl

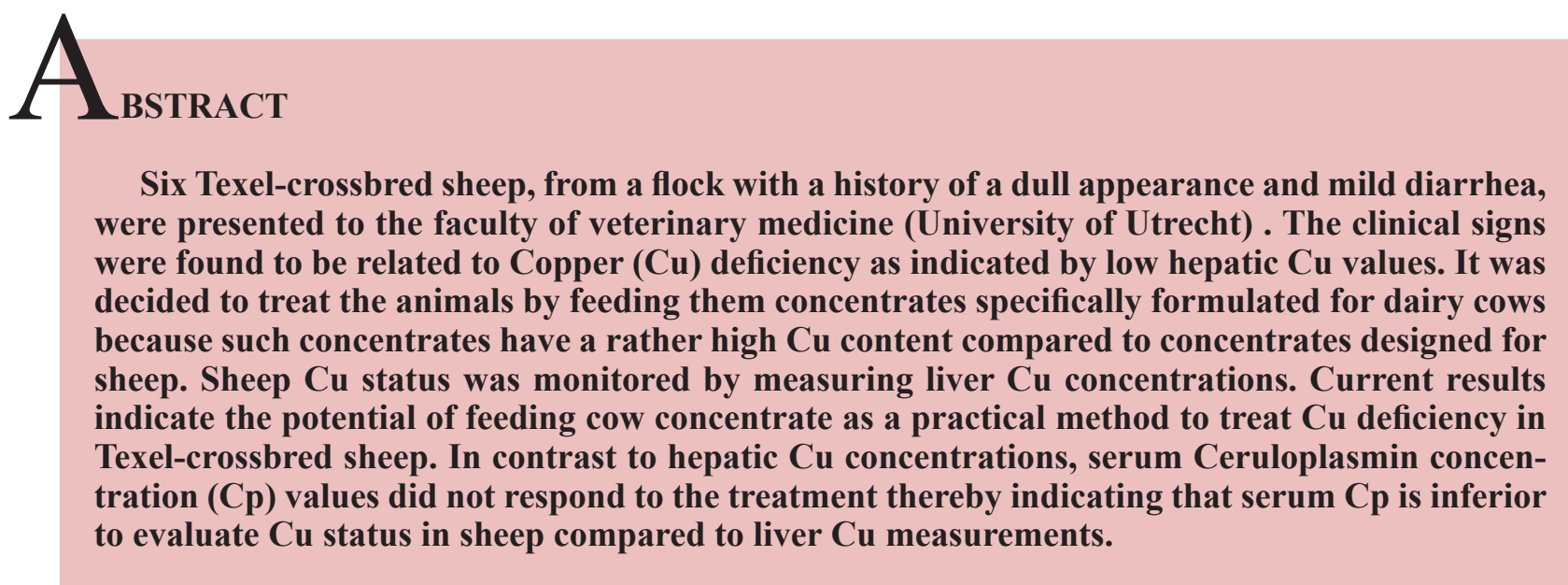

\section{SAMENVATTING}

Zes schapen (kruising texelaar) met klachten van milde diarree en een doffe vacht werden aangeboden aan de Faculteit Diergeneeskunde van de Universiteit Utrecht. De klinische verschijnselen werden gerelateerd aan koper $(\mathrm{Cu})$ deficiëntie op basis van lage $\mathrm{Cu}$-waarden van de lever. Er werd besloten om de schapen te voeren met koeienbrok om het $\mathrm{Cu}$-tekort op te heffen. In vergelijking met schapenbrokken bevatten deze brokken relatief veel $\mathrm{Cu}$. De $\mathrm{Cu}$-status werd gemonitord door $\mathrm{Cu}$-concentraties van de lever te bepalen. Uit de resultaten blijkt dat het voeren van koeienbrok een praktische methode kan zijn om koperdeficiëntie te behandelen bij schapen (kruising texelaar). In tegenstelling tot de lever $\mathrm{Cu}$ waarden, veranderde de serum-ceruloplasmineconcentratie $(\mathrm{Cp})$ niet, wat erop duidt dat serum $\mathrm{Cp}$ een minder betrouwbare indicator is van de koperstatus dan lever $\mathrm{Cu}$.

\section{BACKGROUND}

One of the many sheep breeds in the Netherlands is the Texel breed. The Texel breed is well known for its meat production and also for its high susceptibility to $\mathrm{Cu}$ intoxication (Van den Berg et al., 1983; Underwood and Suttle, 1999). Therefore, Dutch commercial concentrates formulated for sheep are typically not supplemented with $\mathrm{Cu}$ but do contain supplemental sulfate $\left(\mathrm{SO}_{4}\right)$ and molybdenum (Mo), thereby target- ing to depress $\mathrm{Cu}$ absorption (Underwood and Suttle, 1999). Ingestion of sulfate and molybdenum results in the formation of so-called thiomolybdates, which have a high affinity for $\mathrm{Cu}$, thereby rendering $\mathrm{Cu}$ unavailable for absorption (Suttle, 1991; Underwood and Suttle, 1999; Gould and Kendall, 2011). Clearly, this practice is instrumental in preventing $\mathrm{Cu}$ intoxication in Texel sheep, but it may also result in $\mathrm{Cu}$ deficiency in other breeds given the large differences in $\mathrm{Cu}$ requirements between breeds (Van den Berg et al., 
1983; Underwood and Suttle, 1999). Moreover, the risk of $\mathrm{Cu}$ deficiency is increased by a low $\mathrm{Cu}$ content in roughage. Thus, feeding the same particular ration for all sheep may induce either $\mathrm{Cu}$ deficiency or $\mathrm{Cu}$ intoxication depending on the genetic background of the breed and the roughage provided.

\section{CASE PRESENTATION}

In 2015, a sheep owner farming on western peat soils in the Netherlands, reported a high prevalence of dead lambs shortly after parturition to his veterinarian. The lambs were delivered by the youngest ewes of the flock. The whole flock of sheep had been participating in a monitoring program on gastro-intestinal parasites since the observation in 2014 that the sheep suffered from a dull appearance in combination with mild diarrhea. However, given that diarrhea was only observed in the ewes and not in the lambs, it was concluded that the death of the lambs was most likely unrelated to gastro-intestinal parasites.

As grasses from peat soils are known to be generally low in $\mathrm{Cu}$ (Ouweltjes et al., 2002), it was speculated that the combined clinical signs could be related to $\mathrm{Cu}$ deficiency. For screening purposes, initially, several sheep were randomly sampled and only serum $\mathrm{Cu}$ concentrations were determined. Serum $\mathrm{Cu}$ concentrations were found to be $<10 \mu \mathrm{mol} / \mathrm{l}$ (reference: $12-20 \mu \mathrm{mol} / \mathrm{l}$ ), indicating that the animals suffered from $\mathrm{Cu}$ deficiency (Dutch Central Bureau for Livestock Feeding, 2005). It was therefore recommended to implement dietary measures to restore the $\mathrm{Cu}$ status of the animals, but the owner waived this advice. The same happened at six and nine months after the first sampling, when the $\mathrm{Cu}$ status was re-evaluated and serum $\mathrm{Cu}$ concentrations were still below the reference values. Given the poor condition of the animals, the owner finally agreed to transport six young ewes to the Faculty of Veterinary Medicine of the Utrecht University with the aim to confirm $\mathrm{Cu}$ deficiency by measuring liver $\mathrm{Cu}$ concentrations. The liver $\mathrm{Cu}$ concentrations were found to range from 11 to $50 \mathrm{mg} / \mathrm{kg}$ DM (reference: $100-400 \mathrm{mg} / \mathrm{kg} \mathrm{DM}$ ), thereby confirming that all sheep were $\mathrm{Cu}$ deficient (Dutch Central Bureau for Livestock Feeding, 2005). It was then decided to treat the animals by feeding them concentrates specifically formulated for dairy cows. Such concentrates are not supplemented with $\mathrm{SO}_{4}$ and Mo and are typically supplemented with $\mathrm{Cu}$ to reach minimum values of $20 \mathrm{mg} / \mathrm{kg}$ (Dutch Central Bureau for Livestock Feeding, 2005). The authors anticipated that the higher $\mathrm{Cu}$ content of the cattle concentrate together with the higher efficiency of $\mathrm{Cu}$ absorption after the ingestion would be a practical tool to treat $\mathrm{Cu}$ deficiency in the six ewes. For the evaluation of the effects of this treatment to restore the $\mathrm{Cu}$ status, liver biopsies and blood samples were taken. The first sampling was performed after feeding the animals a ration consisting of $50 \%$ sheep concentrate and $50 \%$ grass silage (DM basis) for three weeks. This diet contained a Cu content of $\sim 10 \mathrm{mg} / \mathrm{kg}$ DM. Thereafter, the sheep concentrate was replaced by a dairy cow concentrate, thereby keeping the concentrate to silage ratio constant. This resulted in an estimated dietary $\mathrm{Cu}$ content of $\sim 17,5 \mathrm{mg} / \mathrm{kg} \mathrm{DM}$. The level of feed intake was set to meet the energy requirement of the sheep according to the Dutch Central Bureau for Livestock Feeding i.e. $207 \mathrm{~kJ} \mathrm{NE} / \mathrm{kg}^{0,75}$. After three months, the sampling was repeated to evaluate the effect of the dietary treatment. At both sampling moments, liver biopsies were collected to measure the liver $\mathrm{Cu}$ concentration and jugular blood samples to measure ceruloplasmin (Cp), as serum $\mathrm{Cp}$ has been suggested as a potential indicator of the $\mathrm{Cu}$ status (Blakley and Hamilton, 1985). The diagnostic value of blood samples is of interest because blood sampling is easier, less invasive and less laborious than taking liver biopsies. While no clinical abnormalities, such as swayback were seen, the subjective overall clinical impression of the sheep improved over time. A clear increase in liver $\mathrm{Cu}$ concentrations of $689 \mathrm{mg} / \mathrm{kg}$ DM was observed after the cow concentrate was fed (Figure 1). Feeding cow concentrates also resulted in a numerical increase in serum $\mathrm{Cp}$, but the concentrations were not statistically significantly different from the initial values.

\section{DISCUSSION}

$\mathrm{Cu}$ is a well-known essential trace element and component of many enzymes, such as $\mathrm{Cp}$, tyrosinase and superoxide dismutase. Chronic redundant $\mathrm{Cu}$ contents in the ration of sheep typically results in a hemolytic crisis and death, while $\mathrm{Cu}$ deficiency is associated with growth retardation, diarrhea, low birth weight and weight gain, as well as swayback (enzootic ataxia) (Underwood and Suttle, 1999).

Sheep with $\mathrm{Cu}$ deficiency are commonly treated with $\mathrm{Cu}$ injections or supplemented with $\mathrm{Cu}$ in mineral supplements developed for cattle or special salt blocks, drinking water or by fertilizing pastures with $\mathrm{Cu}$ sulphate. To the authors' knowledge, this is the first case report in which feeding cow concentrates is shown to be a practical method to treat $\mathrm{Cu}$ deficiency in Texel-crossbred sheep. However, caution is warranted to generalize the described strategy, because after three months of feeding the cow concentration, in the present report, the mean hepatic liver $\mathrm{Cu}$ concentration was around 1.8 times higher than recommended for healthy animals (Dutch Central Bureau for Livestock Feeding, 2005), which implies that there is a risk of inducing $\mathrm{Cu}$ intoxication. Despite the high liver $\mathrm{Cu}$ values, no clinical symptoms of $\mathrm{Cu}$ intoxication, such as depression, lethargy, hemoglobinuria and jaundice, were observed.

As the liver $\mathrm{Cu}$ concentrations were clearly above the reference values, it was concluded that the current 


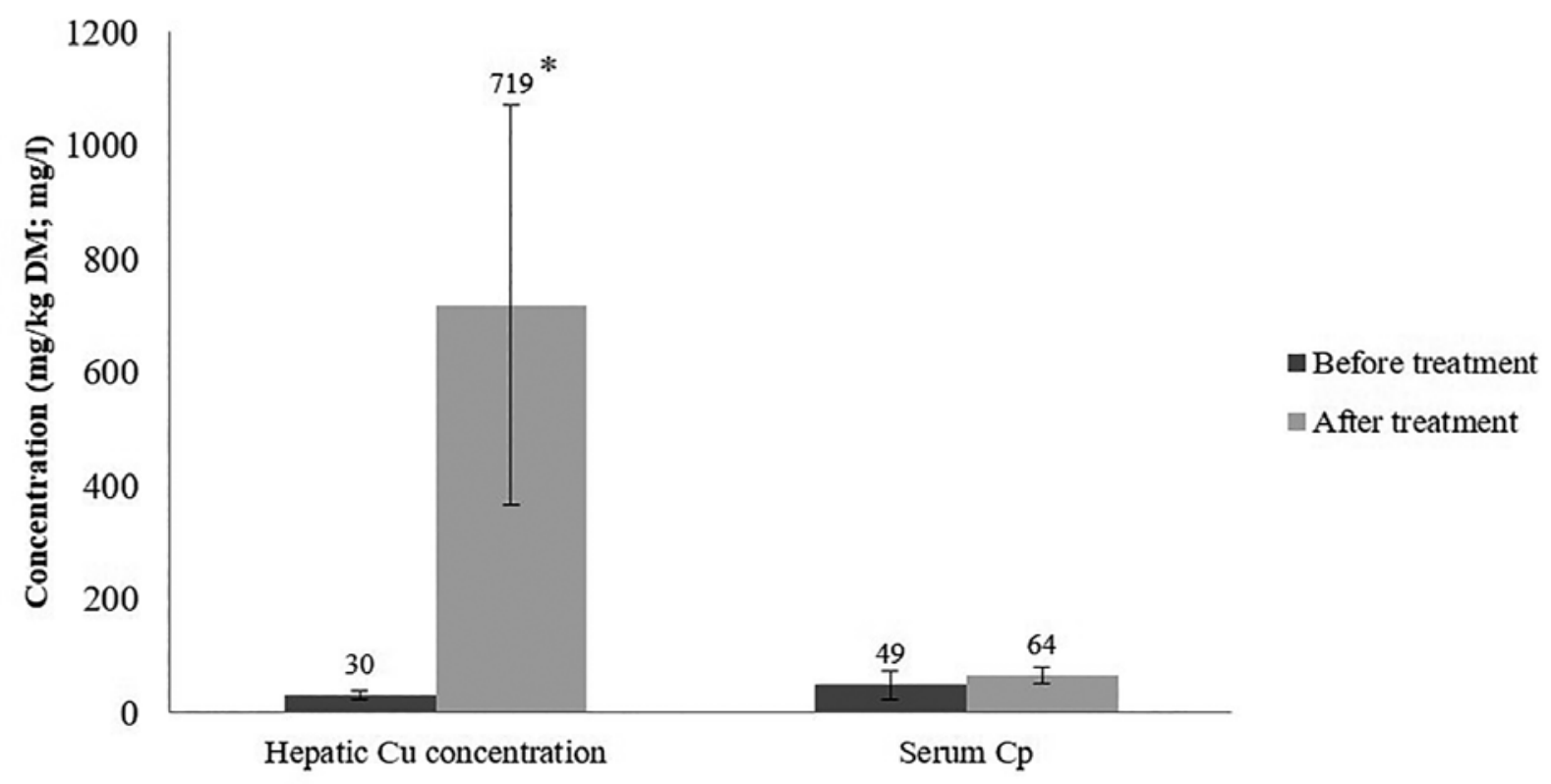

* $\mathrm{p}<0.01$ (students paired t-test) compared to hepatic $\mathrm{Cu}$ concentration before treatment.

Figure 1. Hepatic $\mathrm{Cu}$ concentration and serum $\mathrm{Cp}$ before and three months after treatment.

treatment period was actually too long. Unfortunately, intermediate liver $\mathrm{Cu}$ values were not available, and it is therefore difficult to provide a time span, which is both effective and safe. Furthermore, susceptibility to $\mathrm{Cu}$ toxicity differs substantially between breeds of sheep, which means that it is probably not possible to provide a general effective and safe treatment strategy for all breeds.

The results of the present study indicate the inaccuracy of serum $\mathrm{Cp}$ as an indicator of the $\mathrm{Cu}$ status in sheep. Indeed, $\mathrm{Cp}$ remained relatively constant, despite the increase in liver $\mathrm{Cu}$ concentration. To the authors' knowledge, no reference values for serum $\mathrm{Cp}$ are available in sheep; however, $45-100 \mathrm{mg} / 1$ is considered to be normal in plasma (Radostits and Gay et al., 2007). Given that in serum less $\mathrm{Cu}$ is associated with $\mathrm{Cp}(55 \%)$ than in plasma $(66 \%)$, the reference values for serum are estimated to be around 38-83 mg/l (Radostits and Gay et al., 2007). Based on this estimation, $\mathrm{Cp}$ appeared to be approximately normal in all of the sheep of the present case report, even before treatment. It may be suggested that even in the $\mathrm{Cu}$ deficient sheep, hepatic $\mathrm{Cu}$ stores are sufficient to maintain a certain $\mathrm{Cp}$ activity (Underwood and Suttle, 1999).

Although it is not clear why the sheep in this study developed $\mathrm{Cu}$ deficiency, it seems likely that the animals did not absorb enough $\mathrm{Cu}$ to meet their requirements. Unfortunately, it was not possible to collect and analyze soil and roughage samples in order to investigate whether this was due to a low feed intake, a low roughage $\mathrm{Cu}$ content or a high content of $\mathrm{SO}_{4} / \mathrm{Mo}$ in the roughage.

Furthermore, in the past, pig feed was supplemented with $\mathrm{Cu}$, resulting in $\mathrm{Cu}-$ rich pig manure that was spread on the pasture. Since the restriction in $\mathrm{Cu}$ supplementation in pig feed, the $\mathrm{Cu}$ content of pig manure has decreased, hence increasing the occurrence of $\mathrm{Cu}$ deficiency.

\section{CONCLUSION}

Feeding cow concentrate can be used as a practical tool to treat $\mathrm{Cu}$ deficiency in Texel-crossbred sheep. Given the results, it seems that feeding this concentrate for three weeks is too long, but it remains difficult to generalize this experience for other breeds. Furthermore, serum $\mathrm{Cp}$ concentration was found to be inferior to the liver $\mathrm{Cu}$ measurement for the evaluation of the $\mathrm{Cu}$ status in sheep. Taking liver samples is difficult in practice. Therefore, future research is warranted to find good markers for the detection of $\mathrm{Cu}$ deficiency.

\section{REFERENCES}

Blakley B.R., Hamilton D.L. (1984). Ceruloplasmin as an indicator of copper status in cattle and sheep. Canadian Journal of Comparative Medicine 49, 405-408.

Dutch Central Bureau for Livestock Feeding (2005). Handleiding Mineralenvoorziening Rundvee, Schapen, Geiten. Sixth edition p. 220-226.

Gould L., Kendall N.R. (2011). Role of the rumen in copper and thiomolybdate absorption. Nutrition Research Reviews 24(2), 176-182.

Ouweltjes W., Counotte G., Dobbelaar P. (2002). Kopervoorziening bij melkvee in West-Nederland. Praktijkonderzoek Veehouderij - Praktijkrapport $n r .4$. 
Radostits O.M., Gay C.C., Hinchcliff K.W., Constable P.D. (2007). In: Radostits O.M., Gay C.C., Hinchcliff K.W., Constable P.D. (editors). Veterinary Medicine, a Textbook of the Diseases of Cattle, Horses, Sheep, Pigs and Goats. Tenth edition, Saunders Ltd., p. 1714-1717.

Suttle N.F. (1991). The interactions between copper, molybdenum, and sulfur in ruminant nutrition. Annual Review of Nutrition 11, 121-140.

Underwood E.J., Suttle N.F. (1999). In: Underwood E.J. and Suttle N.F. (editors). The Mineral Nutrition of Livestock. Third edition, CABI Publishing, p. 283-342.
Van der Berg R., Levels F., Van der Schee W. (1983). Breed differences in sheep with respect to the accumulation of copper in the liver. Veterinary Quarterly 5(1), 26-31.

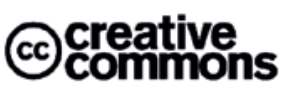

(C) 2020 by the authors. Licensee Vlaams Diergeneeskundig Tijdschrift, Ghent University, Belgium. This article is an open access article distributed under the terms and conditions of the Creative Commons Attribution (CC BY) license (http://creativecommons.org/licenses/by/4.0/).

\section{Enquête bij Vlaamse dierenartsen omtrent hartritmestoornissen bij de hond}

Aan de Faculteit Diergeneeskunde verrichten we momenteel onderzoek naar de diagnose en behandeling van hartritmestoornissen bij de hond.

Hartritmestoornissen komen regelmatig voor bij de hond en zijn een belangrijke oorzaak van hartfalen en plots overlijden. Vaak veroorzaken deze aandoeningen in de initiële fase slechts vage, niet specifieke klachten (bijvoorbeeld inspanningsintolerantie, braken, diarree, soms syncope, tekenen van stress of angst,...). Hierdoor wordt het probleem door de eigenaar of dierenarts vaak pas herkend in een laat stadium, samenvallend met het ontwikkelen van hartfalen. Verder is ook de behandeling van hartritmestoornissen niet eenvoudig, zijn er beperkte medicamenteuze opties en is er gelimiteerde toegang tot interventionele (en curatieve) behandelingsmethoden in de praktijk.

Via deze enquête trachten we te achterhalen hoe frequent dierenartsen in de praktijk geconfronteerd worden met hartritmestoornissen bij de hond en hoe ze op dit moment de diagnose en behandeling aanpakken. Deze informatie helpt ons in de zoektocht naar een betere diagnostische en therapeutische aanpak van deze patiënten. Net daarom is uw deelname zo belangrijk.

De enquête neemt ongeveer 10 minuten van uw tijd in beslag. De verwerking ervan gebeurt binnen het kader van mijn doctoraatsonderzoek aan de faculteit diergeneeskunde, Universiteit Gent.

Wenst $u$ deel te nemen aan de enquête, dan kan dat vanaf 12 januari via de onderstaande link: https://hartritmestoornissen.wixsite.com/cardioteamkhd

Voor verdere vragen omtrent deze enquête kan u steeds mailen naar arnaut.hellemans@ugent.be

Alvast erg bedankt voor uw deelname.

Arnaut Hellemans 